\title{
Prediction of Hevea Progeny Performance in the Presence of Genotype-environment Interaction
}

\author{
Paulo de Souza Gonçalves ${ }^{1 *}$, Mário Luiz Teixeira de Moraes $^{2}$, Marcelo de Almeida Silva ${ }^{3}$, \\ Lígia Regina Lima Gouvêa ${ }^{1}$, Adriano Tosoni da Eira Aguiar ${ }^{1}$ and Reginaldo Brito da \\ Costa $^{4}$ \\ ${ }^{1}$ Instituto Agronômico; Programa Seringueira; C.P. 28; 13001-970; Campinas - SP - Brasil. ${ }^{2}$ Departamento de \\ Fitotecnia; Universidade Estadual Paulista 'Júlio de Mesquita Filho'; Ilha Solteira - SP - Brasil. ${ }^{3}$ APTA Regional \\ Centro Oeste; Jaú - SP - Brasil. ${ }^{4}$ Universidade Federal do Mato Grosso; Cuiabá - MT - Brasil
}

\begin{abstract}
Twenty two open-pollinated Hevea progenies from different parental clones of the Asian origin were tested at five sites in the Northwestern São Paulo State Brazil to investigate the progeny girth growth, rubber yield, bark thickness and plant height. Except for the rubber yield, the analysis of variance indicated highly significant $(p<0.01)$ genotype $x$ environment interaction and heterogeneity of regressions among the progenies. However, the regression stability analysis identified only a few interacting progenies which had regression coefficients significantly different from the expected value of one. The linear regressions of the progeny mean performance at each test on an environmental index (mean of all the progenies in each test) showed the general stability and adaptability of most selected Hevea progenies over the test environments. The few progenies which were responsive and high yielding on different test sites could be used to maximize the rubber cultivars productivity and to obtain the best use of the genetically improved stock under different environmental conditions.
\end{abstract}

Key words: Hevea brasiliensis, stability, adaptability, environmental index, linear regression

\section{INTRODUCTION}

Hevea breeder's concerned with genotypeenvironmental ( $\mathrm{G} \times \mathrm{E}$ ) interaction has led to a greater interest in the studies of genotypic stability across various environments. However, most stability studies in the rubber tree [Hevea brasiliensis (Willd. Adr. ex Juss.) Muell.-Arg.], have been done with only a few genotypes and those materials have been over a limited range of locations. The literature on the genotypeenvironment interaction in Hevea is not extensive. Its effects have been recognized in São Paulo State, Brazil by Gonçalves et al. (1990, 1992, 1998a, 1998b, 1999, 2003 and 2008) and Costa et al. (2000).

Breeders search for the genotypes that show a stable, high yield and good growth performance over the locations. In general, a genotype is considered stable when its performance across the environments does not deviate from the average performance of the group standard genotypes. Several measures have been devised to quantify the yield stability Lin et al. 1986 and Becker and Léon 1988. Searching for a superior genotype with respect to yield performance, a breeder selects among the offspring of the crosses between the promising parents (Dias et al. 2003). To be

\footnotetext{
* Author for correspondence: paulog@iac.sp.gov.br
} 
successful in the selection for the yield, the progeny of a cross should have a sufficient level and variation for both the components of the yield performance, i.e. yield level and yield stability. An important question related to this is whether the level and variation of progeny performance can be predicted on the basis of parent information. The question of heritability of the yield and its stability only addresses the level of yield performance and not the variation of the progeny with respect to both the components. For a breeder, both the level and variation of progeny performance are important.

As Hevea improvement programs became more intense in the Northwestern São Paulo State, and more improved Hevea progenies are produced, the adaptability and stability of selected Hevea progenies to a wide range of environmental conditions must be determined. A better understanding of the genotypic stability and adaptability of many selected progenies over various locations might increase the genetic gains by allowing the breeders to optimally deploy the progenies to sites. This paper reports the stability of 22 open-pollinated Hevea progenies at five locations in the Northwestern São Paulo State, Brazil.

\section{MATERIAL AND METHODS}

\section{Plant material}

The genetic material consisted of 22 half sibprogenies from the open-pollinated seeds, obtained from 22 parental clones phenotypically selected in an $H$. brasiliensis population of the Asian origin established at the Campinas Experimental Station (CES), Instituto Agronômico (IAC). The seeds were collected at the CES, placed in the polyethylene bags and germinated at each site of the progeny tests and taken to their definitive location when they showed two fluxes of the leaves.

\section{Experimental locations}

The progeny tests were grown in a total of five contrasting test environments in the plateau of São Paulo State (Table 1). These locations represented the most important continental climate nontraditional rubber production area. The experimental design at each test location was randomized complete blocks with three replications. Ten plants were used per progeny in each plot at all the locations the plants were spaced at $2.0 \mathrm{~m} \times 2.0 \mathrm{~m}$ in single row. The progenies were assessed when they were three years old.

\section{Measurements}

The girth growth, yield of the rubber, bark thickness and plant height were measured at three years of age for each plant. The yield of rubber was determined by the Hamaker-Morris-Mann (HMM) test modified for three year-old seedlings (Tan and Subramanian, 1976) using the mean dry rubber yield from three-cycle test per plant. The tapping panel was opened $15 \mathrm{~cm}$ from the soil, using the $1 / 2 \mathrm{~S} d / 3$ system, with a total of 35 tappings. The first five samples which corresponded to the "breaking in of the panel" stage, were discarded. The term $1 / 2 \mathrm{~S}$ corresponded to the half spiral cut and the term $d / 3$ expressed the interval between the tappings, i.e. tapping each three days.

The virgin bark samples were removed from the stem as plugs at $20 \mathrm{~cm}$ height on the opposite side of the tapping panel. The bark thickness was measured using the sample for each progeny. The total number of latex vessel rings in the longitudinal and transverse sections of the bark sample was determined as described by Gonçalves et al. (1996). The girth was measured using a steel measuring tape at $0.50 \mathrm{~m}$ from the ground.

\section{Statistical analysis}

An analysis of variance was conducted on the family plot means by using the method of Freeman and Perkins (1971). Finlay and Wilkinson's (1963) concept of the regression coefficient and progeny performance for the traits was used for estimating the stability and adaptability.

The progenies means from each test were regressed on the mean performance of all the genotypes at each location (environments index). All the analyses were performed using the GENES computer program, windows version, 2001 (Cruz 2001). 
Table 1 - Details of experimental locations and planting dates from five different test locations where 22 Hevea progenies were evaluated in São Paulo State, Brazil.

\begin{tabular}{|c|c|c|c|c|c|}
\hline Remarks & & & Locations & & \\
\hline & Mococa & Pariquera-açu & Votuporanga & Jaú & Pindorama \\
\hline Spacing (m) & $2.00 \times 2.00$ & $2.00 \times 2.00$ & $2.00 \times 2.00$ & $2.00 \times 2.00$ & $2.00 \times 2.00$ \\
\hline Planting density & 1 rows $\mathrm{x} 10$ plants & 1 rows $\mathrm{x} 10$ plants & 1 rows $\mathrm{x} 10$ plants & 1 rows $\mathrm{x} 10$ plants & rows $\mathrm{x} 10$ plants \\
\hline & 10 plants/plot & 10 plants/plot & 10 plants/plot & 10 plants/plot & 10 plants/plot \\
\hline Design of experiment & $\mathrm{RBD}^{1}$ & RBD & RBD & RBD & $\mathrm{RBD}$ \\
\hline Number of replications & 3 & 3 & 3 & 3 & 4 \\
\hline Total area (ha) & 0.26 & 0.26 & 0.26 & 0.26 & 0.35 \\
\hline Elevation (m) (mean sea level) & 665 & 25 & 450 & 580 & 560 \\
\hline Latitude (S) & $21^{\circ} 28^{\prime}$ & $24^{\circ} 43^{\prime}$ & $20^{\circ} 25^{\prime}$ & $22^{\circ} 17^{\prime}$ & $21^{\circ} 13^{\prime}$ \\
\hline Longitude (EE) & $47^{\circ} 01^{\prime}$ & $47^{\circ} 57^{\prime}$ & $49^{\circ} 50^{\prime}$ & $48^{\circ} 64^{\prime}$ & $48^{\circ} 56^{\prime}$ \\
\hline Temperature (annual mean) & $24.5^{\circ} \mathrm{C}$ & $20.8^{\circ} \mathrm{C}$ & $22.3^{\circ} \mathrm{C}$ & $21.6^{\circ} \mathrm{C}$ & $21.0^{\circ} \mathrm{C}$ \\
\hline $\begin{array}{l}\text { Annual rainfall }(\mathrm{mm}) \\
\text { (mean annual) }\end{array}$ & 1500 & 1517 & 1480 & 1344 & 1390 \\
\hline Soil type & Eutrustox & Kandiudox & Paleudalf & Paleudalf & Paleudox \\
\hline Terrain & Flat to undulating & Flat to undulating & Flat & Flat & Flat \\
\hline Year of planting & 2000 & 2000 & 2000 & 2000 & 2000 \\
\hline
\end{tabular}

The regression coefficient $(b)$ and the progeny means are presented in Figure 1 as a generalized method of interpretation for analyzing the stability and adaptability of the progenies. The position of particular genotype on the plot indicated the type of stability and performance over the test sites. The genotypes with $b=1.0$ had an average stability since their response to the environments was parallel to the mean response of all the genotypes in the tests. Genotypes with a high mean performance are well adapted to all environments (Okuyama et al. 2005). The genotypes with $b>1.0$ had low stability but were responsive to the improved environmental conditions the genotypes, with $b<1.0$ had high stability and were not sensitive to the changes in the environmental conditions. The ideal genotype was the one with maximum yield potential in all the environments (high mean performance) and maximum stability.

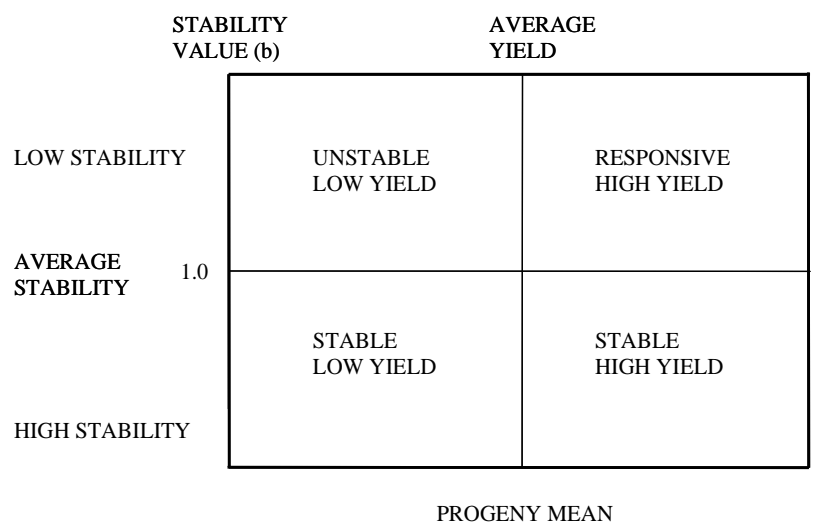

Figure 1 - A generalized interpretation of stability and adaptability for all genotypes by plotting regression coefficients $(b)$ and family means over all tests.

\section{RESULTS AND DISCUSSION}

Except for the rubber yield, the effects of test location by the progeny interaction for the girth growth bark thickness and plant height were highly significant at the $1 \%$ level (Table 2).
Significant linear effects partitioned from the interaction sum of squares suggested that $G \times E$ interaction was partially due to the heterogeneity of the progeny response over various environments. Also, a small but significant portion of the $G \times E$ interaction was nonlinear. 
Table 2 - Analyses of variance for stability parameters for 22 Hevea progenies of three years girth growth, rubber yield, bark thickness and plant height tested at five sites in São Paulo State, Brazil.

\begin{tabular}{|c|c|c|c|c|c|}
\hline \multirow{2}{*}{ Source of variation } & \multirow{2}{*}{ DF } & \multicolumn{4}{|c|}{ Mean squares } \\
\hline & & Girth (cm) & Yield (g) & Bark thickness (mm) & Height (m) \\
\hline Locations & 4 & $985.7419^{* *}$ & $4.2382 *$ & $0.2950 \mathrm{n} . \mathrm{s}$ & $32.4123 * *$ \\
\hline Replications (locations) & 10 & $448.3642 * *$ & $0.2503 \mathrm{n} . \mathrm{s}$ & $0.1950 \mathrm{n} . \mathrm{s}$ & $0.3374 * *$ \\
\hline Progenies & 21 & $91.8947 * *$ & $0.6902 \mathrm{n} . \mathrm{s}$ & $2.2147 * *$ & $1.7979 * *$ \\
\hline Locations x Progenies & 84 & $12.3775 * *$ & $0.2196 \mathrm{n} . \mathrm{s}$ & $0.4881 * *$ & 0.2448 \\
\hline Linear regressions & 21 & $15.2364 * *$ & $0.2429 \mathrm{n} . \mathrm{s}$ & $0.5815^{* *}$ & $0.2262 * *$ \\
\hline Deviation from regressions & 63 & $13.5187 * *$ & $0.3947 \mathrm{n} . \mathrm{s}$ & $0.3947 * *$ & $0.2933 * *$ \\
\hline Residual & 210 & 6.2450 & 0.7090 & 0.1173 & 0.1386 \\
\hline General mean & & 20.8070 & 0.8155 & 3.7871 & 2.5779 \\
\hline Coef. Variation & & 12.01 & 32.65 & 9.04 & 8.10 \\
\hline
\end{tabular}

*, ** significant at 5\%,1\% respectively; n. s. = not significant.

The stability of a genotype across a range of the environments has been measured by its amongenvironment (Plaisted, 1960, Shukla, 1972), the regression of its mean to an environmental index (Finlay and Wilkinson, 1963, Perkins and Jinks, 1968), the residual mean square from the regression (Eberhart and Russell, 1966), or the combinations of these methods. Lin et al. (1986) examined nine stability statistics currently in use and concluded that the regression procedure was valid for providing information on the relative stability among the genotypes included in the experiment if the regression model fit the data. The use of the mean of all the genotypes as the environmental index for the regression has been criticized since it is biased by the genotypes under the consideration (Freeman and Perkins, 1971, Hardwick and Wood, 1972). The assumption of the linearity of the response was also questioned by Namkoong (1978). However, if the number of the genotypes and environments is reasonable large and the environmental range is sufficiently wide, the linear regression using the mean of all the genotypes should be biologically valid (Fripp and Caten, 1971, Fripp, 1972). In this study, the three test means represented 22 progenies per test and the test means ranged from $17.67 \mathrm{~cm}$ to 22.65 $\mathrm{cm}$ for the girth growth and $2.07 \mathrm{~m}$ to $3.07 \mathrm{~m}$ for the plant height. The number of the progenies tested and the range in site quality and height growth were judged to be large enough to justify using the regression method. The coefficient of determination $\left(R^{2}\right)$ for the regression was used in this study to determine how well the linear model fit the data. Essentially, the genotypic stability was measured as the deviation mean square from the regression as proposed by Eberhart and Russell
(1966). A stable progeny is defined as one having $b=1.0$ and $R^{2}=1.0$.

For each Hevea progeny, the mean, regression coefficient $(b)$ and standard error, and the coefficient of determination $\left(R^{2}\right)$ are shown for the girth growth and rubber yield in Table 3 and bark thickness and plant height in Table 4. All $\left(R^{2}\right)$ the values were highly significant, except for the progenies AVROS 49, Tjir 1 and Tjir 16 for the rubber yield. The $b$ statistic interpreted as the genotypic response regression coefficients, ranged from 0.65 to 1.47 for the girth growth, 0.13 to 3.36 for the rubber yield, -8.66 to 18.08 for the bark thickness, and 0.45 to 1.51 for the plant height and was used as a relative measure of the stability over the test sites since such a large part of the total variation was accounted for by the regression. The values for the height regression coefficients (b) were significantly different from 1.0 for relatively few progenies, for rubber yield (4 of 22), bark thickness ( 2 of 22) and for plant height ( 2 of 22) (Tables 3 and 4). The average stability of these Hevea progenies in this region was demonstrated by the majority of the selected progenies having the regression coefficients $(b)$ not significantly different from one. The significant $G \times \mathrm{E}$ interaction sums of the squares in the analysis of variance was contributed by only a few interacting progenies.

The different types of stabilities can be illustrated by plotting the means from three selected progenies against the test means for the girth growth (Fig 2). The progeny C 228 represented a genotype of average stability, as defined by $b$ approximately 1.0, and average performance for the girth growth over all the tests. The changes in its performance across the test sites were 
proportional to the changes in the test site averages and were essentially equal to the test average. The progeny C 259 represented a relatively stable genotype for the girth growth compared with other progenies in this study but was a poor performer for the girth over all the tests. The progeny PR 107 represented a relatively unstable genotype that was sensitive to the site changes and had greater adaptability to favorable and unfavorable sites.

The same patterns of differential reaction of the progenies to three environments for the plant height are shown in Figure 3. Three progenies were used to illustrate the application of the regression analysis in analyzing their relative stabilities and increment to the height in high and low yield hazard sites. There were differences in the plant height among the three progenies. The progeny PB 49 was a stable genotype $(b=0.83)$ over all the levels of the plant height while the progeny Tjir 1 was very instable $(b=1.51)$ and was very tall.

Table 3 - Progenies means for the girth growth and rubber yield, estimated, regression coefficients $\left(b_{i}\right)$ and standard errors (in parenthesis), and the coefficients of determination $\left(R^{2}\right)$ for the regression models, for 22 progenies grown at five sites in São Paulo State, Brazil.

\begin{tabular}{ccccccccc}
\hline \multirow{2}{*}{ Progenies } & \multicolumn{3}{c}{ Girth growth (cm) } & \multicolumn{3}{c}{ Rubber yield (g) } \\
\cline { 2 - 9 } & Means & \multicolumn{2}{c}{$\boldsymbol{b}_{\mathbf{1}}$} & $\boldsymbol{R}^{\mathbf{2} \%}$ & Means & \multicolumn{2}{c}{$\boldsymbol{b}_{\mathbf{1}}$} & $\boldsymbol{R}^{\mathbf{2} \%}$ \\
\hline AVROS 1126 & 24.0850 & 0.8304 & $(0.133)$ & 74.71 & 0.8306 & 1.5295 & $(0.129)$ & 96.29 \\
AVROS 1328 & 18.4605 & 1.1609 & $(0.070)$ & 98.32 & 0.7678 & 1.4937 & $(0.136)$ & 94.88 \\
AVROS 255 & 23.0083 & 0.8687 & $(0.085)$ & 96.83 & 0.9639 & 0.5868 & $(0.113)$ & 40.62 \\
AVROS 352 & 21.8288 & 0.8772 & $(0.055)$ & 84.94 & 0.9294 & 1.4572 & $(0.102)$ & 80.55 \\
AVROS 363 & 22.4233 & 0.8919 & $(0.042)$ & 99.89 & 1.0894 & 1.6730 & $(0.150)$ & 81.08 \\
AVROS 49 & 20.3261 & 0.6996 & $(0.048)$ & 83.53 & 0.8539 & 0.4067 & $(0.164)$ & 15.92 \\
C 228 & 20.5778 & 0.9360 & $(0.064)$ & 99.83 & 0.7300 & 0.6911 & $(0.224)$ & 62.06 \\
C 256 & 19.8750 & 1.0717 & $(0.039)$ & 99.66 & 0.7011 & 0.5959 & $(0.137)$ & 88.49 \\
C 259 & 15.9400 & 0.7096 & $(0.094)$ & 53.30 & 0.5644 & 0.5485 & $(0.252)$ & 69.48 \\
C 290 & 18.4400 & 0.9779 & $(0.116)$ & 75.35 & 0.6161 & 0.3647 & $(0.201)$ & 73.34 \\
C 297 & 20.4788 & 1.4721 & $(0.172)$ & 99.95 & 0.7288 & 1.6475 & $(0.132)$ & 99.92 \\
C 318 & 19.6844 & 1.2141 & $(0.107)$ & 64.22 & 0.7767 & $0.1368 * *$ & $(0.137)$ & 57.96 \\
GT 127 & 17.5283 & 0.8221 & $(0.077)$ & 91.30 & 0.6917 & 0.2589 & $(0.107)$ & 40.12 \\
GT 711 & 22.0588 & 0.6738 & $(0.085)$ & 62.66 & 0.8878 & 0.7404 & $(0.160)$ & 52.96 \\
PB 49 & 22.6883 & 0.7825 & $(0.150)$ & 98.03 & 0.8511 & 1.5723 & $(0.248)$ & 99.90 \\
PB 563 & 18.6627 & 1.1138 & $(0.079)$ & 99.94 & 0.5050 & 0.8244 & $(0.272)$ & 76.14 \\
PB 86 & 22.6583 & 1.2163 & $(0.071)$ & 95.61 & 1.0600 & $2.0649 * *$ & $(0.085)$ & 82.59 \\
PR 107 & 23.8277 & 1.3715 & $(0.089)$ & 86.02 & 1.0722 & 0.9514 & $(0.194)$ & 89.77 \\
RRIM 513 & 21.5094 & 0.6500 & $(0.068)$ & 81.20 & 1.0812 & 0.9423 & $(0.198)$ & 96.74 \\
RRIM 600 & 20.8156 & 1.2865 & $(0.055)$ & 99.10 & 1.2444 & $3.3643 * *$ & $(0.110)$ & 71.73 \\
Tjir 1 & 24.2972 & 1.2818 & $(0.127)$ & 97.73 & 0.6517 & $0.1603 *$ & $(0.113)$ & 10.68 \\
Tjir 16 & 18.5788 & 1.0912 & $(0.134)$ & 85.62 & 0.6139 & 0.2631 & $(0.297)$ & 7.12 \\
\hline
\end{tabular}

$*$ and ** significant for $\mathrm{p}<0.05$ and $\mathrm{p}<0.01$, respectively.

$t(5 \%, 315)=1.96 ; t(1 \%, 315)=2.58$ 
Table 4 - Progeny means for bark thickness and plant height, estimated regression coefficients $\left(b_{i}\right)$ and standard errors (in parenthesis), and the coefficients of determination $\left(R^{2}\right)$ for the regression models, for 22 Hevea progenies grown at five sites in São Paulo State, Brazil.

\begin{tabular}{|c|c|c|c|c|c|c|c|c|}
\hline \multirow{3}{*}{$\begin{array}{c}\text { Progenies } \\
\text { AVROS } 1126\end{array}$} & \multicolumn{4}{|c|}{ Bark thickness (mm) } & \multicolumn{4}{|c|}{ Plant height } \\
\hline & \multirow{2}{*}{$\begin{array}{l}\text { Means } \\
4.4894\end{array}$} & \multicolumn{2}{|c|}{$b_{1}$} & \multirow{2}{*}{$\begin{array}{l}\boldsymbol{R}^{\mathbf{2} \%} \\
0.9711\end{array}$} & \multirow{2}{*}{$\begin{array}{l}\text { Means } \\
2.9872\end{array}$} & \multicolumn{2}{|c|}{$b_{1}$} & \multirow{2}{*}{$\begin{array}{r}\boldsymbol{R}^{\mathbf{2} \%} \\
80.20\end{array}$} \\
\hline & & 0.3272 & $(0.035)$ & & & 0.7970 & $(0.163)$ & \\
\hline AVROS 1328 & 4.1127 & $18.0862 * *$ & $(0.098)$ & 74.6264 & 2.4794 & 1.3483 & $(0.109)$ & 95.01 \\
\hline AVROS 255 & 4.3078 & -1.4619 & $(0.112)$ & 99.5487 & 2.8533 & 0.7718 & $(0.127)$ & 96.36 \\
\hline AVROS 352 & 3.8389 & 0.8795 & $(0.091)$ & 93.5344 & 2.5717 & 0.7967 & $(0.158)$ & 98.18 \\
\hline AVROS 363 & 3.9811 & -1.7920 & $(0.069)$ & 85.8558 & 2.6472 & 0.7813 & $(0.132)$ & 64.70 \\
\hline AVROS 49 & 3.7800 & 2.0198 & $(0.109)$ & 31.0749 & 2.7022 & 1.1602 & $(0.144)$ & 96.29 \\
\hline C 228 & 3.8833 & -0.0368 & $(0.069)$ & 3.8869 & 2.6811 & 1.1140 & $(0.068)$ & 98.81 \\
\hline C 256 & 3.6833 & 0.0118 & $(0.059)$ & 0.0284 & 2.4483 & 1.1925 & $(0.053)$ & 99.99 \\
\hline C 259 & 3.4844 & -8.6601 & $(0.088)$ & 61.1016 & 1.9056 & 0.8641 & $(0.103)$ & 95.77 \\
\hline C 290 & 3.4356 & 4.3676 & $(0.127)$ & 73.6834 & 2.2183 & 0.9965 & $(0.085)$ & 94.26 \\
\hline C 297 & 3.6078 & 1.7808 & $(0.133)$ & 40.4245 & 2.4138 & 1.2063 & $(0.103)$ & 94.41 \\
\hline C 318 & 3.6389 & $5.1260 *$ & $(0.070)$ & 36.2336 & 2.2372 & 1.1072 & $(0.053)$ & 88.55 \\
\hline GT 127 & 3.1644 & -0.8442 & $(0.085)$ & 93.0381 & 2.0455 & 0.6740 & $(0.068)$ & 89.07 \\
\hline GT 711 & 3.7650 & 0.3814 & $(0.055)$ & 0.5759 & 2.9811 & 1.3178 & $(0.144)$ & 94.63 \\
\hline PB 49 & 3.9956 & -1.4232 & $(0.042)$ & 45.6247 & 2.6278 & 0.8341 & $(0.132)$ & 86.46 \\
\hline PB 5/63 & 3.2533 & 0.9809 & $(0.048)$ & 34.0286 & 2.7644 & 1.1872 & $(0.158)$ & 79.91 \\
\hline PB 86 & 4.2178 & 0.5882 & $(0.064)$ & 1.3596 & 2.9267 & 1.1043 & $(0.127)$ & 92.92 \\
\hline PR 107 & 3.8200 & 1.8369 & $(0.094)$ & 54.0213 & 2.8211 & 0.9313 & (0.109) & 99.80 \\
\hline RRIM 513 & 3.9472 & -1.2220 & $(0.073)$ & 42.1003 & 2.4828 & $0.4481 *$ & $(0.163)$ & 59.63 \\
\hline RRIM 600 & 3.7139 & -0.5880 & $(0.164)$ & 15.6100 & 2.8161 & 1.1324 & $(0.107)$ & 85.48 \\
\hline Tjir 1 & 4.0356 & -0.8558 & $(0.066)$ & 7.1631 & 2.9650 & $1.5120 *$ & $(0.072)$ & 99.99 \\
\hline Tjir 16 & 3.1656 & 2.4976 & $(0.116)$ & 93.3244 & 2.1389 & 0.7231 & $(0.050)$ & 91.76 \\
\hline
\end{tabular}

$*$ and $* *$ significant for $\mathrm{p}<0.05$ and $\mathrm{p}<0.01$, respectively.

$t(5 \%, 315)=1.96 ; t(1 \%, 315)=2.58$



Figure 2 - The regression of three progeny means for girth growth on the environmental index (test means). 


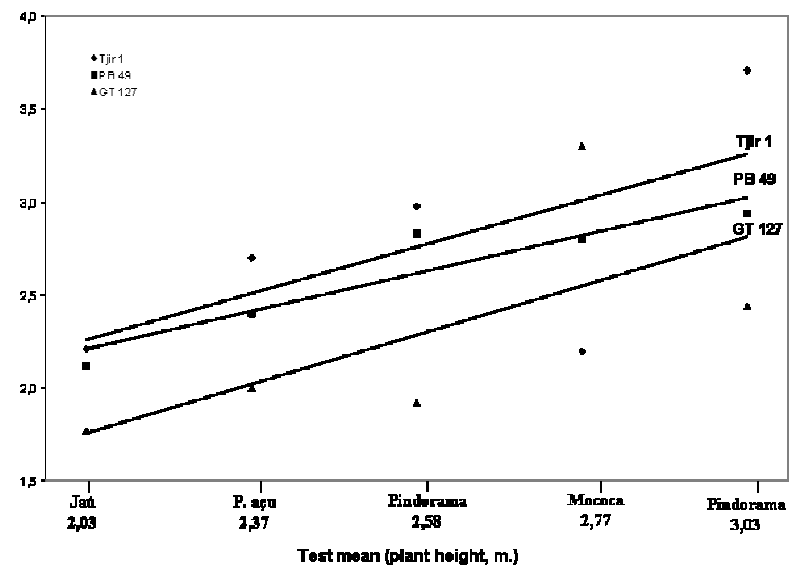

Figure 3 - The regression of the progeny means for plant height on the environmental index (test means).

To identify the genotypes with different levels of mean performances and stabilities in the study, the relationship between the regression coefficients and progeny means for the girth growth was plotted (Fig 4). High progeny mean performance over all the test environments indicated the general adaptability of the progenies. The regression coefficient further measured the stability of the genotype and indicated the kind of environmental condition to which the progeny was adapted. Most of the 22 selected Hevea progenies were classified as high stability genotypes because their linear response to the site averages was higher than $b=$
1.0 (Fig 2 and 4). The progeny $\mathrm{C} 228$ was an example of an average stability genotype with $b=$ 0.93 and average performance in the girth growth (Fig 4). There were some progenies such as PR 107 with $b>1.0$ and high mean performance (Fig 2 and 4), which were classified as the responsive high yield genotypes. These progenies were relatively unstable but performed relatively better on the favorable sites. They were also above average on the poor sites. Only a few progenies such as progeny C 259 were identified as stable low yield genotypes for the girth growth (Fig 4).

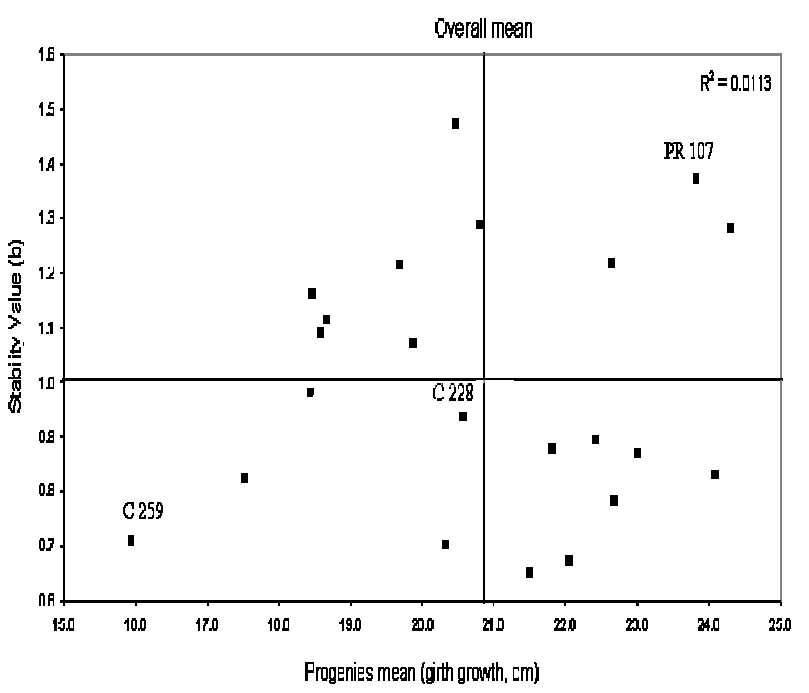

Figure 4 - The relationship of regression coefficients and mean performance for girth of Hevea progenies. 
A significant positive relationship $(r=0.65)$ between the $b$ parameters and the progeny mean performance for rubber yield was noted in this study. This kind of relation has been found in other crops (Finlay and Wilkinson, 1963, Gray, 1982) where the sites, were better. If there was genetic variation in the stability and performance among the progenies, Hevea breeders have the opportunity to select for different stabilities under different environmental conditions and determine the optimum genotypes and managements systems for each environmental condition. For example, the progenies in the responsive high yield group had higher specificity of adaptability to high quality environments and should respond well to the intensive management practices. Although there were few of these progenies found in this study it would be most valuable to use these progenies such as RRIM 600 on high site index lands to maximize the yield and to obtain the best use of genetically improved stock. If a Hevea plantation being established on less favorable sites on over large range of average sites, the progenies in responsive high yield group or in the average stability group with above average performance would be very productive genotypes. The average stability group has general stability and adaptability to all environments.

\section{CONCLUSIONS}

The strong trend in this study for selected Hevea progenies to have average stability and perform in a predictable manner over a range of sites was very valuable information for Hevea breeders. Significant $G \times E$ interaction in the analysis of variance was contributed by very few progenies for the plant height, bark thickness and girth growth. An important implication to the breeding program was that in progenies usually need not be tested over the environmental extremes to determine breeding values. It may be valuable to test over the environmental extremes to identify the few responsive high yield progenies which should be used to increase the rubber cultivars productivity on intensively managed sites.

\section{RESUMO}

Vinte e duas progênies de Hevea de polinização aberta obtidas de diferentes clones fenotipicamente selecionados de uma população de origem asiática Hevea brasiliensis (Willd. Adr. ex Juss.) MuellArg. durante três anos foram testadas em cinco locais. As variáveis perímetro do caule, produção de borracha, espessura da casca e a altura de planta foram determinadas em todos locais no Estado de São Paulo, Brasil. De acordo com as análises de variância, com exceção a produção de borracha, observou-se a existência de interações significativas entre genótipo $\mathrm{x}$ ambiente $(\mathrm{p}<0.01) \mathrm{e}$ heterogeneidade de regressões entre as progênies. Porém, a análise de estabilidade de regressão identificou a interação de poucas progênies cujos coeficientes de regressão foram significativamente diferentes do valor esperado de um. Regressões lineares do desempenho médio das progênies para cada teste em um índice ambiental (média de todas as progênies em cada local) mostrou a estabilidade e adaptabilidade da grande maioria das progênies de Hevea nos diferentes locais. As poucas progênies que foram superiores e altamente produtivas nos diferentes testes de progênies podem ser utilizadas para maximizar a produtividade de cultivares de seringueira e determinar a melhor utilização do ganho genético dos grupos sob as diferentes condições ambientais de cultivo.

\section{REFERENCES}

Becker, H.C. and Leon, J. (1988) Stability analysis in plant breeding. Plant Breeding., 101, 1-23.

Costa, R.B., Resende, M.D.V., Araújo, A.J., Gonçalves, P. de S. and Martins, A.L.M. (2000) Genotypeenvironmental interaction and the number of test locations for the genetic improvement of rubber tree (Hevea) in São Paulo State, Brazil. Genetic Molecular Biology., 23, 179-187.

Cruz, C.D. (2001) Programa Genes: versão windows aplicativo computational em genética e estatística. Editora UFV, Viçosa, 641pp.

Dias, L.A. dos S.; Manta, J.; Cruz, C.D., Barros, E.G. de and Salomão, T.M.F. (2003), Genetic distance and its association with heterosis cacao. Brazilian Archives of Biology and Technology, 46, 339-348. 
Eberhart, S.A. and Russell, W.A. (1966) Stability parameters for comparing varieties. Crop Science., 6, 36-40.

Finlay, K.W. and Wilkinson, G.N. (1963) The analysis of adaptation in a Plant Breeding programme. Australian Journal Agricola Research., 14, 742-754.

Freeman, J.H. and Perkins, J.M. (1971) Environments and genotype-environmental components of variably VIII. Relations between genotypes grown in different environments and measures of these environments. Heredity., 27, 15-23.

Fripp, Y.J. (1972) Genotype-environmental interactions in Schizophyllum commune. II. Assessing the environment. Heredity., 28, 223-238.

Fripp, Y.J. and Caten, C.E. (1971) Genotypeenvironmental interactions in Schizophlyllum commune. I. Analysis and character. Heredity., 27, 393-407.

Gonçalves, P. de S., Bataglia, O.C., Santos, E.R., Ortolani, A.A., Segnini, Jr. I. and Shikasho EH (1998a) Growth trends, genotypes x environments interaction and genetic gain in six year old rubber tree clones (Hevea) in São Paulo State. Genetic Molecular Biology., 21, 115-122.

Gonçalves, P. de S.; Bortoletto, N.; Martins, A.L.M.; Costa, R.B. and Gallo, P.B. (2003) Genotypeenvironment interaction and phenotypic stability for girth growth and rubber yield of Hevea clones in São Paulo State, Brazil. Genetic Molecular Biology., 26, 441-448.

Gonçalves, P. de S.; Cardoso, M.; Colombo, C.A.; Ortolani, A.A.; Martins, A.L.M. and Santos, I.C.I. (1990) Variabilidade genética da produção anual da seringueira: estimativas dos parâmetros genéticos e estudo da interação genótipo x ambiente. Bragantia., 49, 305-320.

Gonçalves, P. de S.; Cardoso, M.; Santos, I.C.I., Martins, A.L.M., Ortolani, A.A. and Colombo, C.A. (1992) Selection of Hevea mother tree adapted to unpredictable annual climatic variability. Brazilian Journal Genetic., 15, 137-147.

Gonçalves, P. de S.; Fujihara; A.K.; Ortolani, A.A., Bataglia, O.C.; Bortoletto, N. and Segnini Jr,. I. (1999) Phenotypic stability and genetic gains in six year girth growth of Hevea clones. Pesquisa Agropecuária Brasileira., 34, 1223-1232.

Gonçalves, P. de S.; Martins, A.L.M.; Bortoletto, N. and Tanzini, M.R. (1996) Estimates of genetics parameters and correlations of juvenille characters based on open pollinated progenies of Hevea. Brazilian Journal Genetic., 19, 105-111.
Gonçalves, P. de S.; Moraes, M.L.T. de; Gouvêa, L.R.L; Aguiar, A.T. da E.; Scaloppi Jr., J.R. (2008) Temporal stability for unpredictable annual climatic variability for Hevea genotype selection. Brazilian Archives of Biology and Technology, 51, 11-18.

Gonçalves, P. S.; Segnini Jr., I.; Ortolani, A.A.; Brioschi, A.P., Landell, M.G. and Souza, S.R. de (1998b) Components of variance and genotype $\mathrm{x}$ environment interaction for annual girth increment in rubber tree. Pesquisa Agropecuária Brasileira., 33, 1328-1337.

Gray, E. (1982) Genotype x environment interactions and stability analysis for forage yield of orchard grass clones. Crop Science., 22, 19-23.

Hardwick. R.C. and Wood, J.T. (1972) Regression methods for studying genotype-environment interactions. Heredity., 28, 209-222.

Lin, C.S.; Binns, M.R. and Lefkovitch, L.P. (1986) Stability analysis: where do we stand? Crop Science., 26, 894-900.

Namkoong, G. (1978) Genotype by environment interaction: some theoretical considerations. In: Proceedings of the Fifth North American Forest Biology Workshop, Florida, United States, p.71-94.

Okuyama, L.A.; Federizzi, L.C. and Barbosa Neto, J.F. (2005), Gain yield stability of wheat genotypes under irrigated and non-irrigated conditions. Brazilian Archives of Biology and Technology, 48, 697-704.

Perkins, J.M. and Jinks J.L. (1968) Environmental and genotype-environmental components of variability. III Multiple lines and crosses. Heredity., 23, 339356.

Plaisted, R.L. (1960) A shorter method for evaluating the ability of selections to yield consistently over locations. American Potato Journal., 37, 166-172.

Shukla, G.K. (1972) Some statistical aspects of partitioning genotype-environmental compo-nents of variability. Heredity., 29, 237-245.

Tan, H. and Subramanian, S. (1976) A five-parents dialell cross analysis for certain characters of young Hevea seedlings. Proceedings of the International Rubber Conference RRIM, Kuala Lumpur, p.13-16. 